\title{
Potential Tracking of Cytotoxic Activities of Mangrove Perepate (Sonneratia alba) Root Extract as an Anti-cancer Candidate
}

\author{
Madyawati Latief, Nelson, Hilda Amanda, Indra L. Tarigan, Siti Aisyah
}

Department of Chemistry, Faculty of Sciences and Technology, Universitas Jambi

\begin{abstract}
Mangrove plants are one of the most extensive biodiversity in Jambi. Besides functioning as a coastal ecosystem protector, it also has any potential of its chemical content. The study of mangrove's bioactive compound is important to generate a new therapeutic agent. This study aims to obtain chemical compounds that have cytotoxic activity, reveal the chemical formula and molecular structure of that active compound, and determine the cytotoxic activity level of active compound from perepat (Sonneratia alba) root extract. The extract was isolated and purified using Liquid Vacuum Chromatography, Graphitation Column Chromatography, and Thin Layer Chromatography. The isolate was characterized using FT-IR spectrophotometry. Our result found that it corresponds to the $\beta$-sitosterol compound group with a high similarly chromophore. Furthermore, both of the extract and isolate was tested for toxicity activity using the Brine Shrimp Lethality Test (BSLT) method using Artemia salina shrimp larvae. Herein, we reported that acetone isolated extract possesses lower cell death average $100 \%$ (start $200 \mu \mathrm{g} / \mathrm{ml}$ ) than isolate extract $80 \%(50 \mu \mathrm{g} / \mathrm{ml})$. Furthermore the toxicity of total extract has LC50 23,98 ( $\mu \mathrm{g} / \mathrm{ml})$, while Isolate 10,04 $(\mu \mathrm{g} / \mathrm{ml})$. From the LC50 value, it can be concluded that the toxicity of the extract lower than the isolate, and both were classified as very toxic compounds, and very potential to be developed into anti-cancer drug compounds.
\end{abstract}

Keywords: Sonneratia alba root, Bioactive, Cytotoxic

\section{Introduction}

Cancer is a very dangerous disease and the second leading cause of death globally after cardiovascular disease. Once cancer is diagnosed, the patient may require medical treatment and specialized care for months and even years. In 2014 WHO reported that an estimated 7.4 million deaths in the world caused by cancer, somehow that is approximately $70 \%$ of deaths in the world caused by cancer occur in both low-and middle-income countries. ${ }^{1}$

Over the last few decades, there has been growing alternative for cancer treatment, such radiation, surgery, and chemotherapy, even synthetic drugs. ${ }^{2}$ Hence, cancer treatment in this way is considered to be unsatisfactory and selective because it has a mechanism of action that not only damages DNA in cancer cells but also in normal cells around it and provides considerable side effects. ${ }^{1,3}$ On the other hand, posing heal and resistance use of that treatment, especially in poor countries or communities, also more costly even might not be available anytime. That is the most reason that encourages people to look for alternative treatment using natural material, because not

Corresponding author: Madyawati Latief. Department of Chemistry, Faculty Sciences and Technology, Universitas Jambi. Email: madyawatilatief@unja.ac.id

Received: 3 April 2020. Revised: 5 June 2020. Published: 1 August 2020. 
only safer regarding genetic effect and lowcost but also it may minimize side effects. The utilization of natural materials (plant), specifically to elucidate and found the sources of new-anticancer compounds which is very potential. Historically, plant extract has been used for a long time as medicine for treating may illnesses. Among the plant, ones of plant that has the potential to be explored are Mangrove Perepate (Soneratia alba). ${ }^{4}$ Unfortunately, the Province of Jambi is one of the provinces that have great potential for mangroves. This plant grows along the coastline in West Tanjung Jabung Regency and East Tanjung Jabung Regency. ${ }^{5}$

The previous research has been reported that the secondary metabolites alkaloids, phenolics, flavonoids, tannins, terpenoids, and saponins are present in S.alba. Technically we need to use various solvents with different polarities to be able to isolate a single compound that can have maximum potential as a drug compound such as n-hexane (non-polar), ethyl acetate (semipolar), and methanol (polar). ${ }^{5}$ The secondary metabolites distribute in both leaf, and fruit which are contain flavonoids, tannins, saponins, and steroids. ${ }^{6}$ Furthermore, triterpenoid (oleanolic acid, ursolic acid, lupeol, squalene) and sterol ( $\beta$-sitosterol and stigmasterol) obtained from the leaves, stems, and bark of $S$. alba's methanol extract promising to act as antioxidants and anticancer agents. ${ }^{7}$ Generally, the secondary metabolites alkaloids, phenolics, flavonoids, tannins, terpenoids, and saponins have the potential as anticancer agent. ${ }^{7-9}$

The antioxidant activity assay of perepat root plant extracts (Sonneratia alba) we did by DPPH (2,2-diphenyl-1-picrylhydrazyl) free radical reduction method and showing that ethyl acetate extract from the parts of perepat plant leaves and fruit had a high percentage of inhibition ie, 79.45 and $69.96 \% .{ }^{10}$ Further assays of antioxidant activity on $S$. alba leaf extract, reported by testing of red blood cells of thalassemia patients. The results in the ability of $S$. alba extract to overcome oxidative stress and the ability of antioxidant activity from $S$. alba is an opportunity to looking for an anticancer compounds candidate. ${ }^{11}$ Based on several studies showing that plants that are active as antioxidants somehow also correlate with anticancer activity. ${ }^{1,3,9}$ This seems that by the existence of research reports regarding the cytotoxic activity of this plant as reports in the previous study which show that the methanol extract of $S$. alba leaves is toxic with an LC-50 value of 743,019 ppm., ${ }^{4,12}$

Moreover, in this study, we isolated chemical compound and elucidated of the structure of the compound which has the potential as an anticancer from $S$. alba root extract. This research was carried out by several methods to achieve the research objectives include isolation, structure determination, and anticancer potential activity through cytotoxicity assay. The isolation protocol was following both granular gradient and purification with various chromatographic techniques. The structure of the isolated compounds then determined based on spectroscopic data, which includes the UVVisible Spectrum and FT-IR spectroscopy. ${ }^{8}$ Moreover, the cytotoxic activity of the isolated compounds was tested by the Brine Shrimp Lethality Test (BSLT) method. ${ }^{13}$

\section{Methods}

\section{Sample and Material Preparation}

The sample is Mangrove's root ( $S$. alba) which was obtained from Kampung Laut Village, Kuala Jambi District, East Tanjung Jabung Regency, Province of Jambi, Indonesia. The samples were taken randomly then dried and mashed to form a powder. All of the organic solvents that we used are 
CH3OH (MERCK); n-hexane, Ethyl Acetate (Sigma-Aldrich), Acetone (MERCK), $\mathrm{HCl}$ (Sigma-Aldrich), and amoxicillin (MERCK) was purchased from a company. Apart from that, we use Larvae of Shrimp was collected from seawater.

\section{Extraction and Fractionation of Organic Compounds}

The mangrove perepat roots were cut into small pieces, dried up, and mashed using a grinder to obtain a powder. The finegrained macerated with n-hexane, ethyl acetate, and methanol for $24 \mathrm{~h}$. Maceration is repeated three times then, concentrated on three different macerates using a rotary evaporator. For each macerate, we examined the cytotoxic activity test. Furthermore, the cytotoxic active extract was carried out by separation and purification. ${ }^{4}$

\section{The fraction of Extract Compound}

To verified the specific compound and its effect, we were carried out separation and purification from the total extract compound to become single-compound by thin-layer chromatography in solvents with various eluents. Furthermore, the active fraction was vacuum using column chromatography and silica gel as a stationary phase with a ratio of 1:20. The sample was prepared by pre-absorption and eluted using eluent with increased polarity effect, then eluent stored in bottles grouped into column fraction of TLC resultants. Each of column fractionation then evaporated using a rotary evaporator and determine for its cytotoxic activity. To the increasing quality of the active fraction, then the total extract compound was separated and purified by both chromatography and recrystallization techniques to obtain a pure active compound which has cytotoxicity activity. ${ }^{14}$ In order that we also carried out identification compounds using UV-Vis.

\section{Cytotoxicity Assay}

The solution was prepared into 3 different concentration $(1000 ; 100 ;$ and $10 \mu \mathrm{g} / \mathrm{ml}$ respectively), and used for analysis. Then, each solution we divided into 3 vials (test) and 1 vial (control). The raw solution made by dissolving $20 \mathrm{mg}$ of the sample into $2 \mathrm{ml}$ of methanol, were dissolved into distilled water to reach $1000 ; 100$; and $10 \mu \mathrm{g} / \mathrm{ml}$ of the solution $500 \mu \mathrm{l} ; 50 \mu \mathrm{l}$; and $5 \mu \mathrm{l}$ from the raw solution into distilled water. The vials contained the solution, were put in a vacuum desiccator then vacuumed until all the solvents evaporated, then added approximately $50 \mu 1$ $\mathrm{DMSO}+2 \mathrm{ml}$ seawater into all of the vials. Moreover, 10 of larvae shrimp were put into the solution, then seawater were added up to $5 \mathrm{ml}$. The cytotoxic activity was observed from Larvae mortality after 24 hours. The resultant obtained were calculated $\mathrm{LC}_{-}{ }_{50}$ by probit analysis. ${ }^{13}$

\section{Results and Discussion}

Separation and Purification of Compound Sonneratia alba root powder was extracted in stages based on the level of polarity using n-hexane (non-polar), ethyl acetate (semipolar), and ethanol (polar) solvents. Each extract was concentrated in vacuo and toxicity was tested by orientation with the BSLT method with bioindicator of A. salina shrimp larvae. ${ }^{13}$ Furthermore, the extract was carried out by separation and purification using column chromatography techniques. ${ }^{4}$

15 grams of ethanol extract was pre-adsorption and put in a vacuum chromatography column $(6 \times 20 \mathrm{~cm})$, then eluted with a mixture of n-hexane: ethyl acetate (9:1 to 2:8) with total $200 \mathrm{~mL}$ each. The eluent is collected in bottles $( \pm 200 \mathrm{~mL})$, each of eluate then analyzed using TLC using UV lamp stain appearance. The eluate with the following same stain pattern then combined into one fraction, concentrated and obtained seven combined 


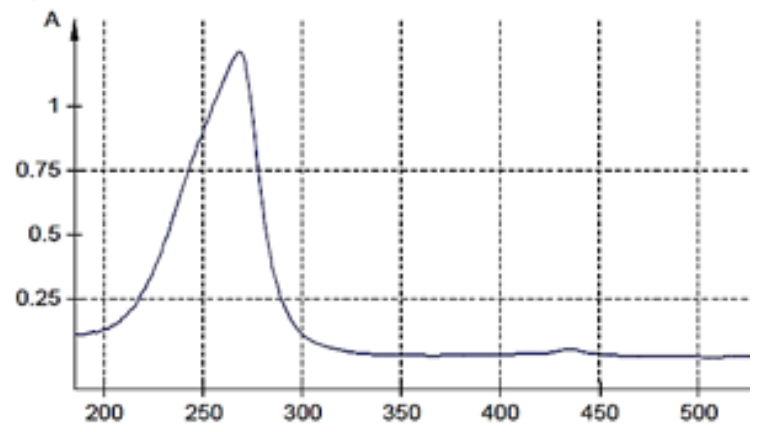

Figure 1. UV-Vis Spectrum of fraction 2 (Isolated compound) Leaves

Table 1. The Result of FT-IR Compound of F.2

\begin{tabular}{lc}
\hline Isolate of $2^{\text {nd }}$ Fraction & Functional Group \\
\hline $3404.89 \mathrm{~cm}^{-1}$ & $\mathrm{O}-\mathrm{H}$ \\
$2938.15 \mathrm{~cm}^{-1}$ & $-\mathrm{CH}$ aliphatic $\left(\mathrm{CH}_{3}\right)$ \\
$2864.86 \mathrm{~cm}^{-1}$ & $-\mathrm{CH}$ aliphatic $\left(\mathrm{CH}_{2}\right)$ \\
$1468.49 \mathrm{~cm}^{-1}$ & Bending Vibration of C-H \\
$13.77 .84 \mathrm{~cm}^{-1}$ & Bending Vibration of C-H \\
$961.25 \mathrm{~cm}^{-1}$ & - \\
$833.95 \mathrm{~cm}^{-1}$ & C-H alkena/aromatic \\
$741.38 \mathrm{~cm}^{-1}$ & - \\
\hline
\end{tabular}

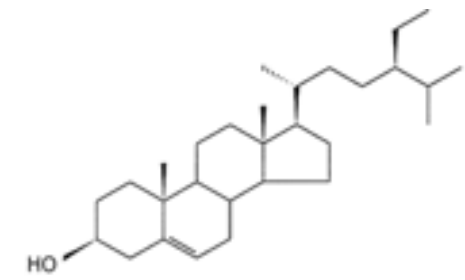

Figure 2. $\beta$-sitosterol structure with the main chain aliphatic $\mathrm{C}-\mathrm{H}$, and the $-\mathrm{OH}$ functional group fractions F1 - F6. Based on result, it appears that the vial in F.2 has sediment, we guest it may content specific compound, it raise a question to verify. Furthermore, the sediment was purified by recrystallization technique then analyze using TLC. The results just one stain appears and it is a compound F2.

\section{The Isolate Belongs to Steroid Groups}

Our preliminary studies, the phytochemical assay of fraction 2 showing that are positive in steroid (seem that belongs to steroid groups). The identification of isolate was carried out using a UV-Vis spectrophotometer and FTIR (Perkin Elmer Inc) spectroscopy. This characterization to confirm and found the compound's group that been isolated. The results of the analysis we presented in Figure 1 and Table 1. From the UV-Vis spectrum, we then predict the functional group of the compound as shown in Table 1.

\section{Characterization of Compound}

The isolates obtained from the results of separation using the Liquid Vacuum Column (LVC) are Steroid compound groups. We verified and analyzed then, using UV-Vis spectrophotometer. Our results from UV-Vis for pure isolates fraction 2 of ethanol root extract of the fast root in Figure 1 showed a maximum absorption peak that is at $266 \mathrm{~nm}$ wavelength with absorbance value 1, 1896 A. The absorption peak corresponds to the molecular structure of the compound which indicates the presence of conjugated bonds. Generally, Based on previous studies, for compounds with conjugated bonds occurring at $\pi \rightarrow \pi^{*}$. Where the electron transition from $\pi \rightarrow \pi *$ is a chromophore that is typical for a $\mathrm{C}=\mathrm{C}$ double bond system. 
Table 2. Toxicity Test Result for Total Ethanol Extract

\begin{tabular}{cccc}
\hline Concentration $(\mu \mathrm{g} / \mathrm{mL})$ & Log- Concentration & Death Average & \% of Death \\
\hline 0 & 0 & 0.3 & 3.33 \\
10 & 1 & 3.3 & 33 \\
50 & 1.69 & 6.3 & 63 \\
200 & 2.30 & 10 & 100 \\
500 & 2.69 & 10 & 100 \\
750 & 2.87 & 10 & 100 \\
1000 & 3.0 & 10 & 100 \\
\hline
\end{tabular}

Table 3. Toxicity Effect of Toxicity Test Result for Isolate Compound

\begin{tabular}{cccc}
\hline Concentration $(\mu \mathrm{g} / \mathrm{mL})$ & Log- Concentration & Death Average & \% of Death \\
\hline 0 & 0 & 1.3 & 13 \\
6.25 & 0.79 & 6.0 & 60 \\
12.50 & 1.09 & 6.3 & 63 \\
25 & 1.39 & 7.6 & 76 \\
50 & 1.69 & 8.0 & 80 \\
100 & 2.0 & 8.0 & 80 \\
150 & 2.17 & 8.0 & 80 \\
\hline
\end{tabular}

This chromophore group is a system that has electron molecular orbitals in orbitals $\pi$, and compounds containing molecular orbitals $\pi$ are compounds containing atoms which have electron pairs conjugated with other atoms that have orbitals $\pi .^{1,15}$

From the FTIR spectrum data analysis, it is known that isolate F.2 has absorption at wavelength number $3404.89 \mathrm{~cm}^{-1}$ with weak absorption which is thought to be an uptake of $-\mathrm{OH}$ functional groups from intermolecular hydrogen bonds. The presence of $-\mathrm{OH}$ group is supported by absorption at wave number $1057 \mathrm{~cm}^{-1}$ from stretching vibrations of primary C-O alcohol. ${ }^{8,10}$ The presence of a sharp band at wave number $2938.15 \mathrm{~cm}^{-1}$ and $2864.86 \mathrm{~cm}^{-1}$ is a stretch of the aliphatic C-H group. The presence of stretching-aliphatic stretch absorption suggests the possibility of the presence of a methyl group $\left(\mathrm{CH}_{3}\right)$ at $2938.15 \mathrm{~cm}^{-1}$ and methylene $\left(\mathrm{CH}_{2}\right)$ at 2864.86 $\mathrm{cm}^{-1}$. This estimation is reinforced by the appearance of absorption in the wavelength number area of $1468.49 \mathrm{~cm}^{-1}$ and $1377.84 \mathrm{~cm}^{-1}$, and there is the absorption of the fingerprint absorption area in the range $650-1000 \mathrm{~cm}^{-1}$, at $961.25 \mathrm{~cm}^{-1}, 833.95 \mathrm{~cm}^{-1}$ and $741.38 \mathrm{~cm}^{-1}$ which shows the bending vibration $\mathrm{C}=\mathrm{CH}$ in the form of aromatic rings.

Based on the results of UV-Vis and FTIR characterization it is assumed that the compound in fraction 2 is a steroid group, high possibility to $\beta$-sitosterol, due to this compound has a similar spectrum with $\beta$-sitosterol compounds, which is confirm by previous studied. ${ }^{15}$

\section{Cytotoxicity Assays}

To verify the toxicity of both total extracts and isolate we have carried out toxicity assays at the variation of concentration. The extract was used $0,10,50,200,500,750$, and 
Table 4. L-C50 Value of Extract and Isolate F.2

\begin{tabular}{ccc}
\hline Sample & Linear Regression Formula & $\mathrm{LC}_{50}(\mu \mathrm{g} / \mathrm{ml})$ \\
\hline Extract & $\mathrm{y}=1.330 \mathrm{x}+3.153$ & 23.98 \\
& $\mathrm{R}^{2}=0,988$ & \\
Isolate & $\mathrm{y}=1.004 \mathrm{x}+3.993$ & 10.04 \\
& $\mathrm{R}^{2}=0.966$ & \\
\hline
\end{tabular}

$1000(\mu \mathrm{g} / \mathrm{ml})$ respectively while, the isolate concentrations were used $0 ; 6.25 ; 12.5 ; 25 ; 50$; 100 ; and $150(\mu \mathrm{g} / \mathrm{ml})$ respectively. In every single concentration, we repeated three times for each sample. The resultant of extract and isolate F2 toxicity present in Table 2 and the data of toxicity test results of isolates are listed in Table 3.

Then the datais analyzed by probit and the curve is obtained between the log concentration (x) and the probit value (y). Based on the straight line equation above, it can be determined the LC50 value of extracts and isolates by entering the value of $y=5$ into a straight line equation of the formed curve, so that the value of $\mathrm{x}$ is obtained. The LC50 value is the antilog of the value of $\mathrm{x}$. LC-50 values from toxicity testing of acetone extract and isolates from pedada leaves can be seen in Table 4.

The toxicity test against Artemia Larvae Saline Leach with Brine Shrimp Lethality Test Method (BSLT)

Mangrove is known by the public with a perepat plant, which is one type of mangrove that has potential as a medicinal ingredient. Coastal communities on the island of Mantehage used materials from the genus Sonneratia mangroves to cure muscle aches, lumbago, rheumatism, malaria, wounds, and tuberculosis. Previous studies have shown that ethyl acetate extract and methanol extract of S. alba leaves are active as antioxidants with 79 percent inhibition, $45 \%$, and $73.88 \%$. Ethanol extract also has active compounds as oxidative stress inhibitors which are tested in vitro by the CAP-e (Cellular Antioxidant Protection in erythrocytes) method. The antioxidant activity of $S$. alba leaves is related to the content of its compounds, namely phenolic, flavonoids and tannins. ${ }^{10,11}$

Phytochemically, several groups of compounds can act as antioxidants, alkaloids, steroids, flavonoids, phenols, and others. From the isolate we obtained, it has similarities with a steroid compound, $\beta$-sitosterol. This compound is known to have good antioxidant activity as can be developed as an anti-oxidative stress drug, which is a cancer factor. ${ }^{15-18}$ The results of our tests are testing the level of total toxicity of the extracts and isolates that we get.

Toxicity is the relative toxicity associated with its potential to cause negative effects on living things which can be influenced by several factors, including the composition and type of toxin, toxicant concentration, duration and frequency of exposure, environmental characteristics, and species of recipient biota. Compounds that have toxicity properties can be classified as: Very Toxic (LC50; 1-30 $\mu \mathrm{g}$ / $\mathrm{ml})$, Medium Toxic (30-100 $\mu \mathrm{g} / \mathrm{ml}$ ), Low toxicity (100-1000 $\mu \mathrm{g} / \mathrm{ml}$ ), and non-toxic ( $>$ $1000 \mu \mathrm{g} / \mathrm{ml}) .^{2,20}$

In this study, we found a group of sitosterol compounds and their $\mathrm{LC}_{50}$ values were analyzed. The $\mathrm{LC}_{50}$ value is an indication of the toxicity for a substance or compound that causes approximately $50 \%$ death in animal testing. The results were present in Table 2 and 3 , showing the toxicity of extracts $\mathrm{LC}_{50}$ values 
$23.98 \mu \mathrm{g} / \mathrm{ml}$ while, $10.04 \mu \mathrm{g} / \mathrm{ml}$ for Isolate $\mathrm{LC}_{50}$ values. The extract is toxic if it has an $\mathrm{LC}_{50} \leq 1000 \mu \mathrm{g} / \mathrm{mL}$ value, a pure compound is said to be toxic if it has an $\mathrm{LC}_{50}$ value of $\leq$ $30 \mu \mathrm{g} / \mathrm{mL}$. If a plant extract is toxic according to the $\mathrm{LC}_{50}$ value with the BSLT method, then the plant can be developed as an anti-cancer drug. This is possible because, in the testing of the extract, there are many secondary metabolites remain, which are suggestions that contain antagonistic properties. Herein, a compound may inhibit the activity of other compounds. Whereas for isolates from the results of phytochemical screening it is known to be a class of Steroid compounds. According to that, most of the compounds in their pure form have toxic properties. ${ }^{16,17}$

\section{Conclusion}

Our finding in this research is that the compound in fraction 2 belongs to the steroid group with high possibility is $\beta$-sitosterol, due to this compound has a similar spectrum with $\beta$-sitosterol compounds. Somehow, the $\beta$-sitosterol compound is widely used as a component of medicine. Moreover, we reported that the toxicity assay of total extracts had $\mathrm{LC}_{50}$ values of $23.98 \mu \mathrm{g} / \mathrm{ml}$ while 10.04 $\mu \mathrm{g} / \mathrm{ml}$ for Isolate $\mathrm{LC}_{50}$ values. It seems that both of them are classified into very toxic compounds, and is promising to be developed into anti-cancer drug compounds. Albeit, the total toxicity of the extract was lower than that of the isolate, indicating that the cytotoxic compound was successfully isolated in fraction 2 .

\section{Acknowledgement}

\section{Funding}

This Present Study was supported by DIPA PNBP, Faculty of Science and Technology, University of Jambi.

\section{Conflict of Interest}

None declared

\section{References}

1. Awad AB, Chinnam M, Fink CS, Bradford PG. $\beta$-Sitosterol activates Fas signaling in human breast cancer cells. Phytomedicine. 2007;14(11):747-754.

2. Katzung BG. Basic \& Clinical Pharmacology. 7th editio. Prentice Hall International; 1995.

3. Francisco Fernandez M, Charfi C, PilotoFerrer J, Lidia González M, Lamy S, Annabi B. Targeting Ovarian Cancer Cell Cytotoxic Drug Resistance Phenotype with Xanthium strumarium L. Extract. Evidence-based Complement Alternative Medicine. 2019;2019:1-13.

4. Latief M, Amanda H, Utami A, Muhaimin, Nurhayati. Isolation of active compounds from the leaf extract of patah kemudi (Abroma augusta L.) and its antiinflammatory activity. J Phys Conf Ser. 2019;1282(1).

5. Latief $M$, Nelson, Nazarudin. Skrining Bioaktivitas Beberapa Tumbuhan Mangrove Asal Kabupaten Tanjung Jabung Timur Provinsi Jambi. Jambi; 2014.

6. Ragasa CY, Ebajo VD, De Los Reyes MM, Mandia EH, Brkljača R, Urban S. Triterpenes and Sterols from Sonneratia. International Journal of Current Pharmaceutical Review Research. 2015;6(6):256-261.

7. Katyal P, Neha B, Robinka K. Flavonoids and Their Therapeutic Potential as Anti Cancer Agents: Biosynthesis, Metabolism and Regulation. World Journal of Pharmaceutical Science. 2014;3(1):21882216.

8. Pierre LL, Moses MN. Isolation and Characterisation of Stigmasterol and B -Sitosterol from Odontonema Strictum (Acanthaceae). Journal of Innovation 
Pharmaceuitcal Biology Science. 2015;2(1):88-96.

9. Lombardi VRM, Carrera I, Cacabelos R. In Vitro Screening for Cytotoxic Activity of Herbal Extracts. Evidencebased Complement Alternative Medicine. 2017;2017:1-7.

10. Latief M, Nazarudin, Nelson. Aktivitas Antioksidan Ekstrak Daun dan Buah Prepat (Sonneratia alba) Asal Tanjung Jabung Timur, Provinsi Jambi. 2015. In: Prosiding SEMIRATA Bidang MIPA BKS-PTN Barat, Universitas Tanjung Pura. ; 2015:112-117.

11. Latief M, Utami A, Fadhilah N, et al. Antioxidant Activity form Perepat Plant (Sonneratia alba) Ethanol Leaf Extract with CAP-E Methods to Overcome Oxidative Stress in Thalassemia. Journal of Pharmaceutical Science Research. 2018;10(1):2160-2162.

12. Melki, Soedharma D, Effendi H, Mustopa AZ. Mustopa. Biopotensi tumbuhan mangrove untuk pencegahan penyakit vibrosis pada udang windu. Maspari Journal. 2011;2:39-47.

13. Mario, Lotulung PDN, Primahan G, Prima SR, Hanafi M. Synthesis and Cytotoxicity assay using Brine Shrimp Lethality Test of Cinchonidine Isobutyrate Ester. Jurnal Kimia Terapan Indonesia. 2017;19(1):2935.

14. Andania MM, Ismed F, Taher M, Ichwan SJA, Bakhtiar A, Arbain D. Cytotoxic activities of extracts and isolated compounds of some potential sumatran medicinal plants against MCF-7 and HSC3 cell lines. Journal of Mathematical and Fundamental Science. 2019;51(3):225242.

15. Rajavel T, Mohankumar R, Archunan G, Ruckmani K, Devi KP. Beta sitosterol and Daucosterol (phytosterols identified in Grewia tiliaefolia) perturbs cell cycle and induces apoptotic cell death in A549 cells.
Scientific Reports. 2017;7(1):1-15.

16. Piironen V, Lindsay DG, Miettinen TA, Toivo J, Lampi AM. Plant sterols: Biosynthesis, biological function and their importance to human nutrition. Journal of Science Food and Agriculture. 2000;80(7):939-966.

17. De-EknamkulW, Potduang B. Biosynthesis of $\beta$-sitosterol and stigmasterol in Croton sublyratus proceeds via a mixed origin of isoprene units. Phytochemistry. 2003;62(3):389-398.

18. Itharat A, Plubrukan A, Kaewpradub N, Chuchom T, Ratanasuwan P, Houghton PJ. Selective cytotoxicity and antioxidant effects of compounds from dioscorea membranacea rhizomes. Natural Product Communicaion. 2007;2(6):643-648.

19. Maiyo F, Moodley R, Singh M. Phytochemistry, cytotoxicity and apoptosis studies of B-sitosterol-3-oglucoside and B -amyrin from prunus Africana. African Journal of Traditional, Complementary, and Alternative Medicine. 2016;13(4):105112

20. Wagner JG. Pharmacokinetics for the Pharmaceutical Scientist. Lancarter: Technomic Pub.Basel; 1993. 